\title{
Effects of altering alfalfa hay quality when feeding steam-flaked versus high-moisture corn grain on ruminal fermentation and lactational performance of dairy cows ${ }^{1}$
}

\author{
J.-S. Eun, ${ }^{2}$ A. W. Kelley, K. Neal, A. J. Young, and J. O. Hall \\ Department of Animal, Dairy, and Veterinary Sciences, Utah State University, Logan 84322
}

\begin{abstract}
This experiment was performed to test a hypothesis that nutritive benefits of feeding high-moisture corn (HMC) would be different when fed with different qualities of alfalfa hay $(\mathrm{AH})$ due to associative effects on ruminal fermentation and nutrient utilization efficiency. Eight multiparous lactating Holstein cows were used; 4 were surgically fitted with ruminal cannulas. Days in milk averaged $184 \pm 10.7$ at the start of the experiment. The experiment was performed in a duplicate $4 \times 4$ Latin square design. Within each square, cows were randomly assigned to a sequence of 4 diets during each of the four 21-d periods (14 d of treatment adaptation and $7 \mathrm{~d}$ of data collection and sampling). A $2 \times 2$ factorial arrangement was used; fair-quality $\mathrm{AH}$ [FAH; 39.6\% neutral detergent fiber (NDF) and $17.9 \%$ crude protein $(\mathrm{CP})]$ or high-quality $\mathrm{AH}(\mathrm{HAH}$; $33.6 \% \mathrm{NDF}$ and $21.9 \% \mathrm{CP}$ ) was combined with steamflaked corn (SFC) or HMC to form 4 treatments: $\mathrm{FAH}$ with SFC, FAH with HMC, HAH with SFC, and $\mathrm{HAH}$ with HMC. The AH was fed at $32 \%$ dry matter (DM) content, whereas SFC or HMC was included at $17 \%$ DM content. Quality of AH did not affect DM intake, whereas feeding HMC decreased DM intake, regardless of quality of AH. Digestibility of DM was greater for cows fed HAH compared with those fed FAH (70.1 vs. $67.6 \%)$. Digestibility of NDF increased by feeding HMC (67.6 vs. $58.4 \%$ ), but not by quality of $\mathrm{AH}$. Under FAH, starch digestibility decreased by feeding HMC compared with SFC (85.7 vs. $95.0 \%$ ), but it was similar under $\mathrm{HAH}$, resulting in an interaction between quality of $\mathrm{AH}$ and type of corn grain (CG). Feeding different qualities of AH did not affect milk yield; however, feeding $\mathrm{HMC}$ decreased milk yield in FAH diet, causing an $\mathrm{AH} \times \mathrm{CG}$ interaction. Efficiency of milk yield/DM intake was improved due to feeding $\mathrm{HMC}$, regardless of
\end{abstract}

Received May 30, 2014.

Accepted August 15, 2014.

${ }^{1}$ Approved as Journal Paper Number 8685 of the Utah Agricultural Experiment Station, Utah State University, Logan.

${ }^{2}$ Corresponding author: jseun@usu.edu the quality of the $\mathrm{AH}$. In addition, dietary $\mathrm{N}$ utilization for milk $\mathrm{N}$ tended to increase by feeding $\mathrm{HMC}$, but it was not influenced by quality of AH. Yield of microbial protein increased by feeding $\mathrm{HAH}$ diets compared with FAH diets, whereas feeding the HMC diet increased microbial protein yield under the $\mathrm{HAH}$ diet, leading to an interaction between and $\mathrm{AH}$ and $\mathrm{CG}$. Overall results in this experiment indicate that feeding HMC in AH-based diets improved feed efficiency as well as $\mathrm{N}$ utilization efficiency, regardless of quality of $\mathrm{AH}$.

Key words: dairy cow, high-moisture corn, alfalfa hay, feed efficiency, microbial protein yield

\section{INTRODUCTION}

Forage quality affects feed intake and energy density, lactational performance, cow health, and feed cost. In addition, recent increases in grain and protein supplement prices have been unprecedented, making forage quality of paramount importance for reducing purchased feed costs and improving income-over feed cost. Dairy producers in the western United States use alfalfa hay $(\mathbf{A H})$ to make up the majority of the forage portion in dairy diets, and great emphasis has been placed on producing high-quality $\mathrm{AH}$ with an average chemical composition for CP, NDF, and ADF of 21.3, 38.3, and 26.7\% DM, respectively (Holt et al., 2010). Feeding high-quality AH (HAH) provides enough CP and forage NDF to support potential milk production by dairy cows; however, ruminal microbes degrade alfalfa protein too rapidly, resulting in excessive excretion of nitrogenous waste by the animal. This process results in inefficient utilization of feed $\mathrm{N}$ with high $\mathrm{CP}$ degradability of $\mathrm{AH}$ in the rumen and limits optimal microbial CP (MCP) synthesis. It also increases energy cost to convert ruminal ammonia- $\mathrm{N}\left(\mathrm{NH}_{3}-\mathrm{N}\right)$ to urea and elevates $\mathrm{N}$ excretion into the environment (Holt et al., 2013). Consequently, the full benefit of alfalfa protein is not realized due to its poor $\mathrm{N}$ utilization by the animal. Feeding carbohydrates that are more extensively fermented in the rumen may improve utilization of the $\mathrm{CP}$ in $\mathrm{HAH}$ through stimulation of MCP synthesis. 
Ruminal starch digestibility, rate, and extent of VFA production, and postruminal starch flow and digestion vary in response to physiological status of the cow as well as to type and genotype of grain, growing conditions, and both physical and chemical processing methods of the grain (Nocek and Tamminga, 1991). The addition of highly digestible carbohydrate to the diet is a common method of increasing the energy available to the cow. Although ruminally fermentable carbohydrate can increase MCP yield (Nocek and Tamminga, 1991; Krause et al., 2002), high amounts of fermentable carbohydrate increase the risk of ruminal acidosis. Highmoisture corn (HMC) has consistently greater starch digestion in the rumen, the small intestine, and the total tract compared with dry-rolled and steam-flaked corn (SFC; Wilkerson et al., 1997; Knowlton et al., 1998; Firkins et al., 2001). Several (Zogg et al., 1961; San Emeterio et al., 2000), but not all experiments (Clark et al., 1973) feeding HMC, have reported improved lactational performance of dairy cows. Inconsistent effects of HMC in lactation dairy diets have been caused by various factors, including cows differing in the physiological state and interactions with other forages and concentrates (Ekinci and Broderick, 1997). The objectives of this study were to investigate the effects of, and interaction between quality of $\mathrm{AH}$ [fair-quality $\mathrm{AH}$ (FAH) vs. HAH] and type of corn grain [CG; SFC vs. $\mathrm{HMC}]$ on nutrient digestibility, ruminal fermentation characteristics, and lactational performance in midlactation dairy cows. We hypothesized that nutritive benefits of feeding HMC would be different between FAH and HAH due to their associative effects on ruminal fermentation and nutrient utilization efficiency.

\section{MATERIALS AND METHODS}

The dairy cows used in this study were cared for according to the Live Animal Use in Research Guidelines of the Institutional Animal Care and Use Committee at Utah State University. The study was conducted at the Caine Dairy Research Center (Wellsville, UT), Utah State University from May to August, 2013.

\section{Cows and Experimental Design and Diets}

Eight multiparous lactating Holstein cows were used; 4 were surgically fitted with ruminal cannulas. Days in milk averaged $184 \pm 10.7$ at the start of the experiment. Average BW was $741 \pm 63.5 \mathrm{~kg}$ at the beginning of the experiment and $801 \pm 70.6 \mathrm{~kg}$ at the end of the experiment, showing positive BW gain over all experimental periods.

The experiment was performed in a double $4 \times 4$ Latin square design. Within each square, cows were ran- domly assigned to a sequence of 4 diets during each of the four $21-\mathrm{d}$ periods (14 $\mathrm{d}$ of treatment adaptation and $7 \mathrm{~d}$ of data collection and sampling). A $2 \times 2$ factorial arrangement was used; FAH $(39.6 \% \mathrm{NDF}$ and $17.9 \%$ $\mathrm{CP})$ or $\mathrm{HAH}(33.6 \% \mathrm{NDF}$ and $21.9 \% \mathrm{CP}$; Table 1$)$ was combined with SFC (8.26\% CP and $61.6 \%$ starch) or HMC (8.66\% CP and $65.4 \%$ starch; Table 1) to form 4 treatments: FAH with SFC (FAH-SFC), FAH with HMC (FAH-HMC), HAH with SFC (HAH-SFC), and HAH with HMC (HAH-HMC; Table 2). Diets were isonitrogenous across treatments, averaging $16.0 \%$ $\mathrm{CP}$ and are typical of high-producing dairy cows in the Intermountain West (i.e., Utah, Idaho, Wyoming, Montana, and parts of Arizona and Nevada) with $32 \%$ of the forage $\mathrm{DM}$ coming from $\mathrm{AH}$ and with the remaining forage considered to come from corn silage. Experimental diets contained 16.6 or $17.3 \%$ of corn grains (SFC or HMC) under FAH- or HAH-based TMR, respectively (Table 2).

Whole corn (Pioneer 3730; Pioneer Hi-bred International Inc., Johnston, IA) was processed with a mobile roller mill (model number ATG3600B; Automatic Equipment Manufacturing Co., Pender, NE), which resulted in a mean particle size of $1,017 \mu \mathrm{m}$. The ground HMC was ensiled in a $2.4-\times 9.0-\mathrm{m}$ bag (Ag-Bag International Ltd., Blair, NE). The SFC grain used in this study was supplied by Cache Commodities (Ogden, UT). The average thickness of the SFC was 2.0 $\mathrm{mm}$, and its bulk density was averaged at $0.35 \mathrm{~kg} / \mathrm{L}$. Alfalfa was preserved as sun-cured hay and processed for approximately $15 \mathrm{~min}$ in a TMR wagon (model 455; Roto-Mix, Dodge City, KS).

Cows were housed in individual tie-stalls fitted with rubber mattresses, bedded with straw, and were fed a TMR for ad libitum intake with at least $10 \%$ of daily feed refusal. All cows were individually fed twice daily at 0830 and $1500 \mathrm{~h}$ with approximately 70 and $30 \%$ of total daily feed allocation at each feeding, respectively. Feed offered and refused was recorded daily, and daily samples were collected to determine DMI. Cows had free access to water.

Cows were milked twice daily at 0400 and $1600 \mathrm{~h}$. Milk production was recorded daily throughout the experiment. Cows were turned outside to a dry lot for exercise for at least $1 \mathrm{~h}$ daily in the morning after being milked. Milk was sampled during the a.m. and p.m. milking on 3 consecutive days (d 16 to 18) in each period. Milk samples were preserved with Broad Spectrum Microtabs II (D\&F Control Systems Inc., San Ramon, CA), and were stored at $4^{\circ} \mathrm{C}$. Individual milk samples were analyzed for fat, true protein, lactose, and MUN by the Rocky Mountain DHIA Laboratory (Wellsville, UT). Milk composition was expressed on weighted milk yield of a.m. and p.m. samples. Milk fat 
Table 1. Chemical composition (means $\pm \mathrm{SD})$ of forages and corn grains $\left(\mathrm{n}=4^{1}\right)$

\begin{tabular}{lcccccc}
\hline & \multicolumn{3}{c}{ Forage $^{2}$} & & \multicolumn{2}{c}{ Corn grain $^{3}$} \\
\cline { 2 - 4 } \cline { 6 - 7 } \% of DM & FAH & HAH & Corn silage & & SFC & HMC \\
\cline { 2 - 4 } DM, \% & $93.3 \pm 0.94$ & $94.4 \pm 0.49$ & $35.9 \pm 1.01$ & & $89.1 \pm 2.47$ & $81.4 \pm 2.20$ \\
OM & $88.9 \pm 0.99$ & $88.4 \pm 0.28$ & $93.8 \pm 0.28$ & & $98.1 \pm 0.16$ & $98.1 \pm 0.05$ \\
CP & $17.9 \pm 0.26$ & $21.9 \pm 0.97$ & $7.08 \pm 0.290$ & & $8.26 \pm 0.401$ & $8.66 \pm 0.810$ \\
NDF & $39.6 \pm 1.29$ & $33.6 \pm 1.55$ & $41.8 \pm 2.20$ & & $13.6 \pm 0.35$ & $13.0 \pm 2.03$ \\
ADF & $29.2 \pm 0.49$ & $23.9 \pm 0.81$ & $21.8 \pm 0.61$ & & $3.52 \pm 0.095$ & $3.13 \pm 0.544$ \\
Starch & ND $^{4}$ & ND & 33.4 & & 61.6 & 65.4 \\
\hline
\end{tabular}

${ }^{1}$ Number of sample replicates.

${ }^{2} \mathrm{FAH}=$ fair-quality alfalfa hay; $\mathrm{HAH}=$ high-quality alfalfa hay.

${ }^{3} \mathrm{SFC}=$ steam-flaked corn; HMC $=$ high-moisture corn.

${ }^{4} \mathrm{ND}=$ not determined.

and protein yields were calculated by multiplying milk yield from the respective day by fat and true protein concentration of the milk on an individual cow. To convert milk true protein to milk N, 6.38 was used as the conversion factor (DePeters and Cant, 1992), and total milk $\mathrm{N}(\mathrm{kg} / \mathrm{d})$ was calculated as milk true protein/6.38 + MUN, where milk true protein and MUN were expressed in kilograms per day. Calculation of 3.5\% FCM

Table 2. Ingredients and chemical composition (means \pm SD) of the experimental diets fed to lactating dairy cows $\left(n=4^{1}\right)$

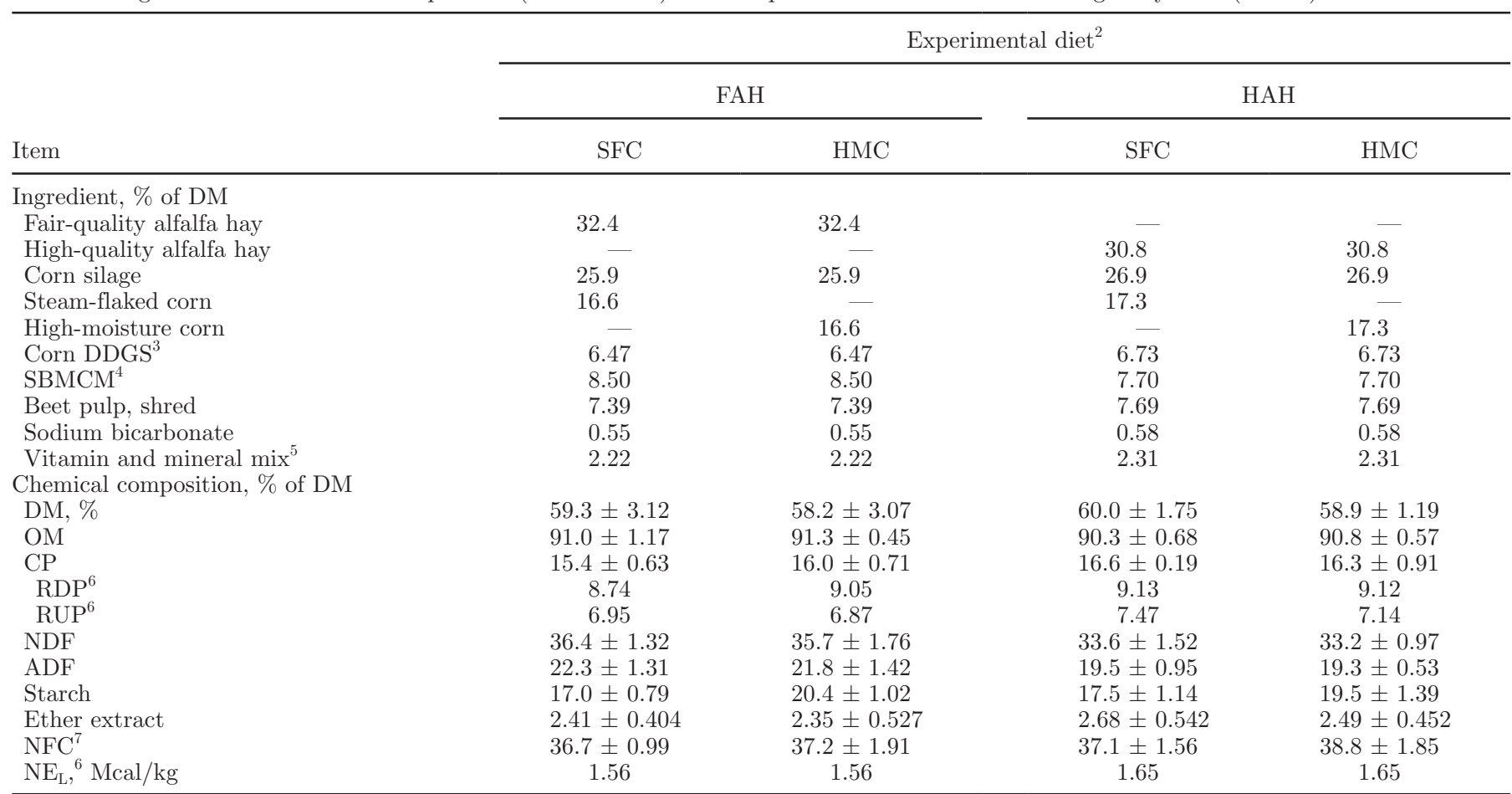

${ }^{1}$ Number of sample replicates.

${ }^{2} \mathrm{FAH}-\mathrm{SFC}=$ fair-quality alfalfa hay $(\mathrm{FAH})$ and steam-flaked corn (SFC) diet; FAH-HMC = FAH and high-moisture corn (HMC) diet; HAH$\mathrm{SFC}=$ high-quality alfalfa hay $(\mathrm{HAH})$ and $\mathrm{SFC}$ diet; HAH-HMC $=\mathrm{HAH}$ and HMC diet.

${ }^{3}$ DDGS $=$ dried distillers grains with solubles.

${ }^{4}$ Mixture of soybean meal and canola meal at a ratio of 50:50 on a DM basis.

${ }^{5}$ Formulated to contain (per $\mathrm{kg}$ of $\mathrm{DM}$ ): $226.7 \mathrm{mg}$ of Se (from sodium selenite), 9,278.7 $\mathrm{mg}$ of $\mathrm{Cu}$ (from copper amino acid complex), 40,537.4 $\mathrm{mg}$ of $\mathrm{Zn}$ (from zinc amino acid complex), 38,653.4 $\mathrm{mg}$ of $\mathrm{Mn}$ (from manganese amino acid complex), $552.6 \mathrm{mg}$ of Co (from cobalt carbonate), 1,234,585.2 IU of vitamin A, 152,808.1 IU of vitamin D, 3,815.1 IU of vitamin E, and $295 \mathrm{mg}$ of Rumensin (Elanco Animal Health, Greenfield, IN).

${ }^{6}$ Based on tabular values (NRC, 2001).

${ }^{7} \mathrm{NFC}=100-\mathrm{CP}-\mathrm{NDF}-$ ether extract - ash. 
was done using the equation $0.4324 \times$ milk yield $(\mathrm{kg} / \mathrm{d})$ $+16.216 \times$ fat yield $(\mathrm{kg} / \mathrm{d})$, whereas ECM was calculated using the equation $0.327 \times$ milk yield $(\mathrm{kg} / \mathrm{d})+$ $12.95 \times$ fat yield $(\mathrm{kg} / \mathrm{d})+7.65 \times$ true protein yield (kg/d) (DRMS, 2014).

\section{Feed Sampling and Analysis}

Corn silage, AH, and HMC were sampled weekly to determine DM concentration and composited for each period. Diets were adjusted weekly to account for changes in DM concentration. Samples of the TMR fed and orts for individual cows were collected daily during the data collection period, dried at $60^{\circ} \mathrm{C}$ for 48 $\mathrm{h}$, ground to pass a 1-mm screen (standard model 4; Arthur H. Thomas Co., Swedesboro, NJ), and stored for subsequent analyses.

Analytical DM concentration of samples was determined by oven drying at $135^{\circ} \mathrm{C}$ for $3 \mathrm{~h}$ (AOAC International, 2000; method 930.15), and OM content was determined by ashing at $550^{\circ} \mathrm{C}$ for $5 \mathrm{~h}$ (AOAC International, 2000; method 942.05). The concentration of $\mathrm{N}$ was determined using a $\mathrm{N}$ analyzer (Flash 2000; CE Elantech Inc., Lakewood, NJ; AOAC International, 2000; method 990.03). The NDF and ADF concentrations were sequentially determined using a fiber analyzer (200/220; Ankom Technology, Macedon, NY) according to the methodology supplied by the company, which is based on the methods described by Van Soest et al. (1991). Sodium sulfite was used in the procedure for NDF determination and pretreatment with heatstable amylase (type XI-A from Bacillus subtilis; Sigma-Aldrich Corp., St. Louis, MO). Ether extract was measured (AOAC International, 2000; method 2003.05) using a fat analyzer (XT20; Ankom Technology). In addition, samples of corn grain (SFC and HMC), TMR, orts, and fecal samples were analyzed for starch by the Dairyland Laboratories Inc. (Arcadia, WI) according to Knudsen (1997).

Feed DM and nutrient digestibility were measured during the last week in each period using acid-insoluble ash (AIA) as an internal marker (Van Keulen and Young, 1977). Fecal samples (approximately 100 g, wet weight) were collected for each cow from the rectum twice daily (a.m. and p.m.) every $12 \mathrm{~h}$, moving ahead $2 \mathrm{~h}$ each day for the 5-d sampling of feces beginning on d 15. This schedule provided 12 representative samples of feces for each cow. Samples were composited across sampling times for each cow, dried at $60^{\circ} \mathrm{C}$ for $72 \mathrm{~h}$, ground to pass a 1 -mm screen (standard model 4; Arthur H. Thomas Co.), and stored for chemical analysis. Apparent total-tract DM and nutrient digestibilities were calculated from concentrations of AIA and nutrients in diets fed, orts, and feces. Intake of digested
NDF was calculated from NDF intake and concentrations of AIA and NDF in diets fed, orts, and feces using the following equation: intake of digested NDF $(\mathrm{kg} / \mathrm{d})$ $=$ intake of NDF $(\mathrm{kg} / \mathrm{d}) \times\left\{100-\left[100 \times\left(\mathrm{AIA}_{\mathrm{d}} / \mathrm{AIA}_{\mathrm{f}}\right)\right.\right.$ $\left.\times\left(\mathrm{NDF}_{\mathrm{f}} / \mathrm{NDF}_{\mathrm{d}}\right)\right\}$, where $\mathrm{AIA}_{\mathrm{d}}=$ AIA concentration in the diet actually consumed, $\mathrm{AIA}_{\mathrm{f}}=\mathrm{AIA}$ concentration in the feces, $\mathrm{NDF}_{\mathrm{f}}=$ concentration of the NDF in the feces, and $\mathrm{NDF}_{\mathrm{d}}=$ concentration of the NDF in the diet actually consumed. Intake of undigested NDF was calculated from the following equation: intake of undigested NDF $(\mathrm{kg} / \mathrm{d})=$ intake of NDF $(\mathrm{kg} / \mathrm{d})$ - intake of digested NDF (kg/d) (Eun and Beauchemin, 2005).

\section{Measurements of Ruminal $\mathrm{pH}$ and Fermentation Characteristics}

Ruminal $\mathrm{pH}$ was continuously measured for 2 consecutive days starting on d 18, using the Lethbridge Research Centre Ruminal pH Measurement System (LRCpH; Dascor Inc., Escondido, CA) as described by Penner et al. (2006). Readings in pH buffers 4 and 7 were recorded before placing the $\mathrm{LRCpH}$ system in the rumen. Ruminal $\mathrm{pH}$ readings were taken every 30 $\mathrm{s}$ and stored by the data logger. After about $48 \mathrm{~h}$ of continuous $\mathrm{pH}$ measurement, the $\mathrm{LRCpH}$ was removed from the rumen, washed in $39^{\circ} \mathrm{C}$ water, and millivolt readings were recorded in $\mathrm{pH}$ buffers 4 and 7 . The daily ruminal $\mathrm{pH}$ data was averaged for each minute and summarized as minimum $\mathrm{pH}$, mean $\mathrm{pH}$, and maximum $\mathrm{pH}$. In addition, daily episodes, duration (h/d), and area $(\mathrm{pH} \times \min )$ when ruminal $\mathrm{pH}$ was less than 5.8 were calculated. The threshold 5.8 was assigned because it has been defined by others (Nocek, 1997; Maekawa et al., 2002; Beauchemin and Yang, 2005) to cause subclinical ruminal acidosis.

Ruminal contents were sampled 0,3 , and $6 \mathrm{~h}$ after the a.m. feeding of ruminally cannulated cows in one square on d 20 and 21. Approximately $1 \mathrm{~L}$ of ruminal contents was obtained from the anterior dorsal, anterior ventral, medial ventral, posterior dorsal, and posterior ventral locations within the rumen, composited by cow, and strained through a polyester screen (pore size: 355 $\mu \mathrm{m}$; B. \& S. H. Thompson, Ville Mont-Royal, QC, Canada). Five milliliters of the filtered ruminal fluid was added to $1 \mathrm{~mL}$ of $1 \%$ sulfuric acid and samples were retained for $\mathrm{NH}_{3}-\mathrm{N}$ determination. Concentration of $\mathrm{NH}_{3}-\mathrm{N}$ in the ruminal contents was determined as described by Rhine et al. (1998). Another $5 \mathrm{~mL}$ of the filtered ruminal fluid was taken at $3 \mathrm{~h}$ after the a.m. feeding and added to $1 \mathrm{~mL}$ of $25 \%$ of meta-phosphoric acid, and the samples were retained for VFA determination. The VFA were quantified using a gas chromatograph (model 5890; Hewlett-Packard Labs, Palo Alto, CA) with a capillary column $(30 \mathrm{~m} \times 0.32 \mathrm{~mm}$ i.d., 
1- $\mu \mathrm{m}$ phase thickness, Zebron ZB-FAAP; Phenomenex Inc., Torrance, CA) and flame-ionization detection. The oven temperature was $170^{\circ} \mathrm{C}$ held for $4 \mathrm{~min}$, which was then increased by $5^{\circ} \mathrm{C} / \mathrm{min}$ to $185^{\circ} \mathrm{C}$, and then by $3^{\circ} \mathrm{C} / \mathrm{min}$ to $220^{\circ} \mathrm{C}$, and held at this temperature for 1 min. The injector temperature was $225^{\circ} \mathrm{C}$, the detector temperature was $250^{\circ} \mathrm{C}$, and the carrier gas was helium (Eun and Beauchemin, 2007).

\section{Urine Sampling and Analysis for MCP Production}

On d 15 to 17, spot urine samples were collected from each cow at 0600 and $1800 \mathrm{~h}$ for a total of 6 samples per cow (Holt et al., 2013). Urine samples were acidified using $4 \mathrm{M} \mathrm{HCl}$ to $\mathrm{pH}<4.0$ and composited by cow per period. Samples were frozen and stored at $-40^{\circ} \mathrm{C}$. Samples were thawed at a later date for analysis and diluted with 39 parts diluent to 1 part urine. Diluent consisted of $0.202 \%$ sodium 1-heptane sulfonic acid and $0.086 \%$ ammonium dihydrogen phosphate $\left(\mathrm{NH}_{4} \mathrm{H}_{2} \mathrm{PO}_{4}\right)$, and the solution was brought to a $\mathrm{pH}$ of 2.1 using $4 \mathrm{M}$ $\mathrm{HCl}$. Using the ratio of urinary purine derivatives (PD) to creatinine is an accepted way to estimate the MCP flow to the duodenum (Shingfield and Offer, 1998). The PD and creatinine were analyzed using an HPLC instrument (Waters Corp., Milford, MA) according to the procedures of Shingfield and Offer (1999). Supply of MCP was estimated based on estimates of urinary excretion of PD according to the method of Chen and Gomes (1992) and Janicek et al. (2008).

\section{Statistical Analyses}

Data were summarized for each cow by measurement period. All data were statistically analyzed using the mixed-model procedure in SAS (SAS Institute, 2013). Data for intake, digestibility, milk production, $\mathrm{pH}$ and VFA profiles, and MCP yield were analyzed with a model that included the effects of quality of $\mathrm{AH}$ in the diet (FAH vs. HAH), type of CG (SFC vs. HMC), and their interaction. Cow and period were the terms of the random statement. Data for $\mathrm{NH}_{3}-\mathrm{N}$ concentration were analyzed using the model described above, except that the fixed effect of time after feeding was included using the repeated option. For each variable analyzed, cow nested within treatment was subjected to 3 covariance structures: compound symmetry, autoregressive order 1 , and unstructured covariance. The covariance structure that resulted in the lowest values for the Akaike information criterion and the Schwartz Bayesian criterion was used (Littell et al., 1998). Residual errors were used to test main effects and interactions. Differences were considered significant at $P \leq 0.05$, and trends were discussed at $P>0.05$ to $P<0.10$.

\section{RESULTS AND DISCUSSION}

\section{Nutrient Profiles of Forages, CG, and Experimental Diets}

Chemical compositions of $\mathrm{AH}$ are similar to those with comparable quality reported by Mertens (2002) and Holt et al. (2013), with concentrations greater for $\mathrm{CP}$ and less for NDF in HAH versus FAH (21.9 vs. $17.9 \%$ and 33.6 vs. $39.6 \%$, respectively; Table 1). Nutrient profiles were similar between SFC and HMC, except that HMC contained 3.8 percentage units greater starch concentration, which resulted in slight increases in starch and NFC concentrations in experimental diets containing HMC (Table 2).

\section{Intake and Digestibility of DM and Nutrients}

Intakes of DM and nutrients were not affected due to quality of $\mathrm{AH}$, except that $\mathrm{ADF}$ intake decreased by feeding HAH-based diets (Table 3). In contrast, cows fed HMC decreased or tended to decrease $(P=0.06)$ intakes of DM, OM, CP, and fiber compared with those fed SFC. Feeding different types of CG did not influence starch intake. No $\mathrm{AH} \times \mathrm{CG}$ interaction was observed in intakes of DM and nutrients. Feeding HAH-based diets increased total-tract digestibility of DM and tended to increase $\mathrm{OM}$ and $\mathrm{CP}$ digestibilities $(P=0.08)$. However, total-tract digestibilities of NDF and ADF were not different between FAH- and HAH-based diets. Feeding different types of CG resulted in similar digestibilities of DM and OM. In contrast, feeding HMC-containing diets caused increased total-tract digestibilities of $\mathrm{CP}$, NDF, and ADF. Total-tract digestibility of starch decreased when feeding FAH-based diets compared with $\mathrm{HAH}$ diets, which resulted from the sizable reduction of starch digestibility by feeding HMC-containing diet with $\mathrm{FAH}$, but not $\mathrm{HAH}$, resulting in an $\mathrm{AH} \times \mathrm{CG}$ interaction.

The overall results of feeding different qualities of $\mathrm{AH}$ in the diets observed in this study were generally expected, based on a previous study performed with similar diets using the same experimental design (double $4 \times 4$ Latin square; Holt et al., 2013). We reported no difference in intakes and digestibilities of DM, CP, $\mathrm{NDF}$, and $\mathrm{ADF}$ in response to feeding $\mathrm{FAH}$ vs. $\mathrm{HAH}$ (Holt et al., 2013). Hence, the discussion of these effects is limited in this paper, because the focus of the current study was to understand the interaction between quality of $\mathrm{AH}$ and $\mathrm{CG}$ processing in the diets, rather than the effects of quality of $\mathrm{AH}$ per se.

Given similar concentrations of major nutrients (CP, NDF, and NFC) between SFC- and HMC-containing diets, the negative effects of feeding HMC-containing 
Table 3. Intake of DM and nutrient and total-tract digestibility of lactating dairy cows fed different qualities of alfalfa hay and types of corn grain

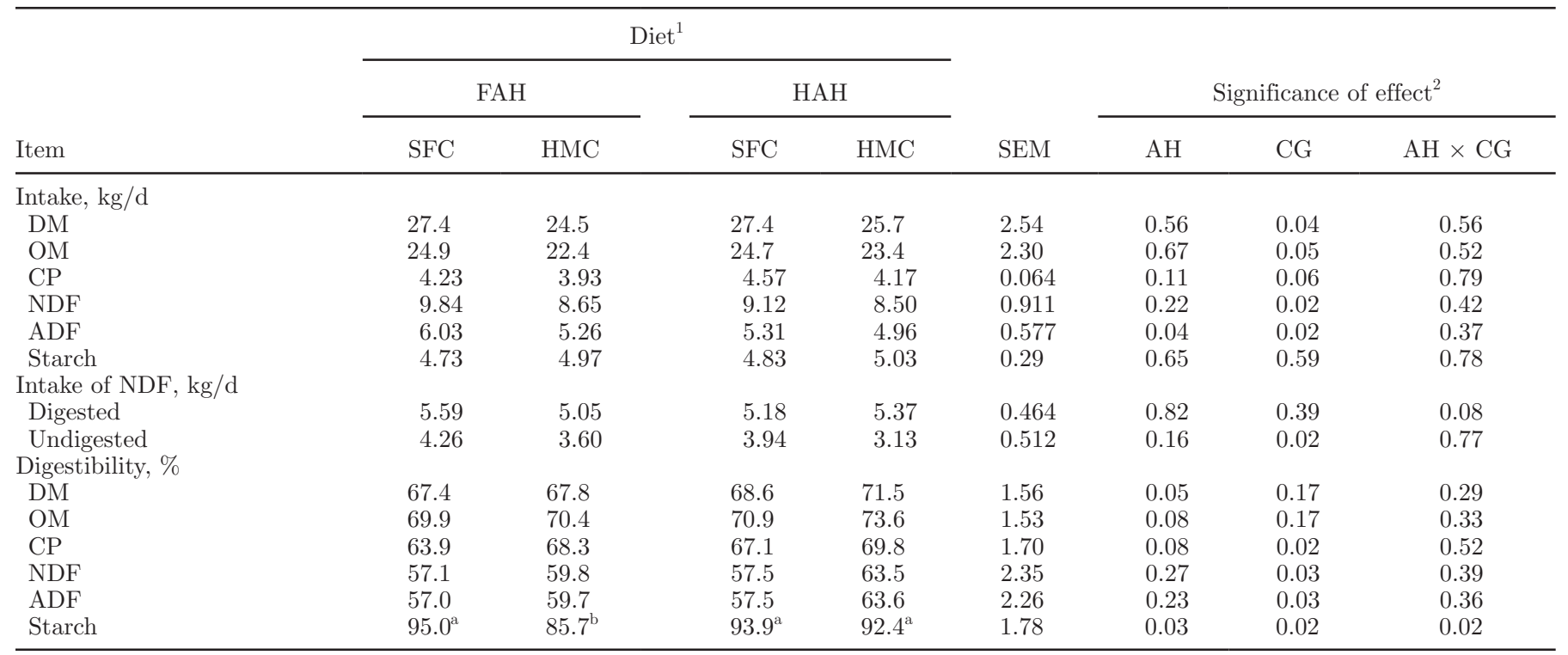

${ }_{\mathrm{a}, \mathrm{b}}$ Means within a row with different superscripts differ $(P<0.05)$.

${ }^{1} \mathrm{FAH}-\mathrm{SFC}=$ fair-quality alfalfa hay $(\mathrm{FAH})$ and steam-flaked corn (SFC) diet; FAH-HMC = FAH and high-moisture corn (HMC) diet; HAH$\mathrm{SFC}=$ high-quality alfalfa hay $(\mathrm{HAH})$ and $\mathrm{SFC}$ diet; HAH-HMC $=\mathrm{HAH}$ and HMC diet.

${ }^{2} \mathrm{AH}=$ quality of alfalfa hay in the $\operatorname{diet}(\mathrm{FAH}$ vs. $\mathrm{HAH}) ; \mathrm{CG}=$ type of corn grain in the diet (SFC vs. HMC); $\mathrm{AH} \times \mathrm{CG}=$ interaction between $\mathrm{AH}$ and $\mathrm{CG}$.

diets on intakes of DM and nutrients observed in the current study was unexpected, and the mechanism whereby feeding HMC decreased the intakes is difficult to explain. Allen (2000) suggested that DMI will continue to increase until gut fill is no longer a limiting factor and then decrease with an excess of metabolic fuels. Because NDF intake decreased due to feeding HMC in both FAH and HAH diets in the current study, differences in physical fill were not likely responsible for differences in intakes of DM and nutrients. The amount of rumen-degraded starch consumed must be maintained to an adequate concentration to maximize the $\mathrm{NE}_{\mathrm{L}}$ density while decreasing the risk of ruminal acidosis and feed intake associated with excessive rumen degraded starch intake (Firkins, 2008). However, increasing ruminal fermentability of CG can decrease average meal size for cows, implying that increasing the concentration of rumen-degraded starch in a diet above a threshold would be expected to decrease DMI proportionately (Firkins, 2008). Oba and Allen (2003) observed that HMC treatment decreased DMI by 1.7 $\mathrm{kg}$ compared with dry-ground corn treatment when fed in high-starch diets, but had no effect when fed in low-starch diets. Consistent with the treatment effects on DMI, meal size was greater for the dry-ground corn treatment compared with the HMC treatment when cows were fed high-starch diets (Oba and Allen, 2003). Similarly, Harvatine et al. (2002) reported a decrease in
DMI by $1.1 \mathrm{~kg} / \mathrm{d}$ when cows were fed SFC compared with those fed dry-ground corn. Collectively, the effects on feed intake reported across a broad range of corn processing is primarily due to a change in ruminal starch degradability. Cows fed HMC in the current study may have received all necessary nutrients from lower feed intakes, decreasing the DMI. Because of increased digestibilities of $\mathrm{CP}$ and NDF in response to feeding $\mathrm{HMC}$, calculated digestible intakes of CP (2.89 vs. 2.80 $\mathrm{kg} / \mathrm{d}$ ) and NDF (5.43 vs. $5.29 \mathrm{~kg} / \mathrm{d}$ ) between SFC- and HMC-containing diets were similar, implying that cows tested in this study may have consumed a similar level of nutrients for metabolism. Another possibility is that shifts in energy metabolism due to feeding HMC may have contributed to the downward regulation of intakes of cows fed HMC. Further research needs to be done to determine the mechanism of regulation of feed intake when early-lactation cows are fed high-forage diets with CG that are processed differently.

Fiber digestion by ruminants can be altered by grain processing. Total-tract digestion of NDF was lower for HMC than for dry-rolled, flaked, or whole corn with both lactating cows and feedlot cattle (Owens and Soderlund, 2006). This depression in NDF digestion may have resulted from reduced ruminal fiber digestion coupled with low ruminal pH. Ekinci and Broderick (1997) and Valadares Filho et al. (2000) reported that increased intake of NFC from $\mathrm{HMC}$ reduced ruminal $\mathrm{pH}$ 
and, thus, depressed NDF digestibility. However, feeding different types of $\mathrm{CG}$ did not affect overall ruminal $\mathrm{pH}$ patterns in the current study as will be discussed later, and so overall ruminal fermentative conditions were not interfered with by feeding HMC. Calsamiglia et al. (2008) reported that the effect of ruminal $\mathrm{pH}$ on NDF digestibility was relatively small above $\mathrm{pH} 6.0$, but digestibility of NDF decreased sharply below this $\mathrm{pH}$ threshold. Therefore, feeding HMC in AH-based diets can increase ruminal NDF digestion without interfering with ruminal physiological conditions.

\section{Milk Production, BW, and Caloric Efficiency}

Cows fed HAH increased milk yield compared with those fed with FAH (30.0 vs. $28.8 \mathrm{~kg} / \mathrm{d}$; Table 4), whereas dietary treatments did not affect yields of $3.5 \%$ FCM and ECM. Type of CG did not influence milk yield. However, feeding HMC decreased milk yield under $\mathrm{FAH}$, but not under $\mathrm{HAH}$, leading to an $\mathrm{AH}$ $\times$ CG interaction. Feeding FAH-based diets increased milk fat concentration compared with HAH-based diets (3.52 vs. $3.32 \%$ ), whereas type of CG did not influence milk fat concentration, resulting in an $\mathrm{AH} \times \mathrm{CG}$ interaction. Increased milk fat concentration due to feeding
HMC under FAH can be associated with decreased DMI; Firkins et al. (2001) stated that increased milk fat concentration coupled with decreased DMI below $25.8 \mathrm{~kg} / \mathrm{d}$ was likely associated with increased lipolysis of adipose tissue with decreasing DMI. Milk fat yield was similar across dietary treatments. In addition, milk true protein concentration and yield was not different between treatments. Feeding different qualities of $\mathrm{AH}$ resulted in inconsistent effects on feed efficiency; based on yield of milk as well as ECM, the feed efficiency was not affected, whereas feeding FAH-based diets increased the efficiency based on 3.5\% FCM yield compared with $\mathrm{HAH}$. Cows fed HMC increased all feed efficiencies compared with those fed SFC, regardless of quality of $\mathrm{AH}$. In addition, dietary $\mathrm{N}$ utilization efficiency for milk $\mathrm{N}$ tended to increase due to feeding $\operatorname{HMC}(P=$ 0.07 ), but it was not affected by quality of $\mathrm{AH}$.

Feed efficiencies are used to evaluate herd productivity and profitability, and increased feed efficiencies are associated with greater milk yield, loss in body condition, high-quality forages, and improved feed digestibilities (Britt et al., 2003). The greatest factor affecting energy availability to the lactating dairy cow is digestibility (NRC, 2001). Feeding HMC-containing diets increased NDF digestibility regardless of quality

Table 4. Milk production and composition and efficiencies of DM and N use for milk production of lactating dairy cows fed different qualities of alfalfa hay and types of corn grain

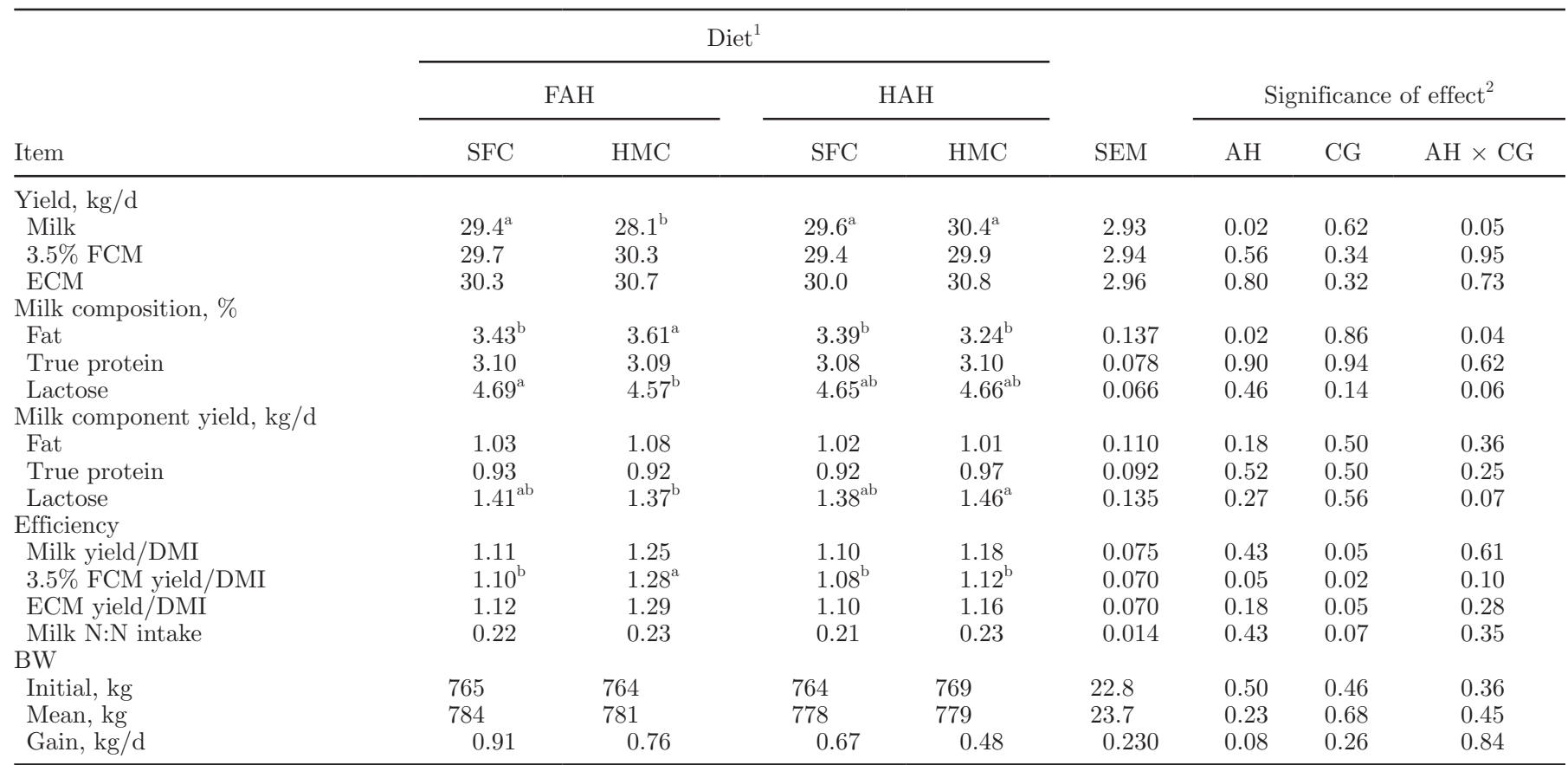

${ }^{\mathrm{a}, \mathrm{b}}$ Means within a row with different superscripts differ $(P<0.05)$.

${ }^{1}$ FAH-SFC $=$ fair-quality alfalfa hay (FAH) and steam-flaked corn (SFC) diet; FAH-HMC = FAH and high-moisture corn (HMC) diet; HAH$\mathrm{SFC}=$ high-quality alfalfa hay $(\mathrm{HAH})$ and $\mathrm{SFC}$ diet; HAH-HMC $=\mathrm{HAH}$ and HMC diet.

${ }^{2} \mathrm{AH}=$ quality of alfalfa hay in the diet $(\mathrm{FAH}$ vs. $\mathrm{HAH}) ; \mathrm{CG}=$ type of corn grain in the diet (SFC vs. HMC); $\mathrm{AH} \times \mathrm{CG}=$ interaction between $\mathrm{AH}$ and $\mathrm{CG}$. 
of $\mathrm{AH}$ in the current study as discussed earlier. Oba and Allen (1999) reported that a one percentage unit increase in NDF digestibility (measured in vitro or in situ) was associated with a $0.25 \mathrm{~kg} / \mathrm{d}$ increase in $4 \%$ FCM yield. The increased NDF digestion due to feeding HMC observed in the current study resulted in similar milk yield even with reduced DMI, causing the overall improvement in feed efficiencies in this study. Additionally, feeding HMC increased CP digestibility in our study, leading to a similar digestible CP intake between SFC- and HMC-containing diets. Thus, higher dietary CP intake by feeding SFC-containing diets could reduce ME allowable milk due to additional energy required to convert excess protein into urea (NRC, 2001; Abdoun et al., 2006). This would result in decreased feed efficiencies coupled with less efficient ME utilization when cows were fed SFC.

No difference in mean BW existed between treatments (Table 4). Cows tested in this study gained 0.71 $\mathrm{kg} / \mathrm{d}$, on average, while on trial, and cows fed FAH tended to increase $\mathrm{BW}$ gain $(P=0.08)$ compared with those fed HAH. However, type of CG did not influence BW gain. The relatively low values of feed efficiencies in our current study reported earlier may have resulted from sizable energy partitioning toward BW gain. Numerically decreased BW gain due to feeding HMC compared with $\mathrm{SFC}$ (0.62 vs. $0.79 \mathrm{~kg} / \mathrm{d}$, respectively; $P=0.26)$ may have contributed to the increased feed and $\mathrm{N}$ utilization efficiencies because of feeding HMC by channeling more $\mathrm{ME}$ toward milk production rather than BW gain.

\section{Ruminal Fermentation Characteristics}

Minimum and mean $\mathrm{pH}$ in the rumen were similar across dietary treatments (Table 5), and mean $\mathrm{pH}$ of at least 6.30 was maintained. This provides evidence of minimal negative effects on physiological conditions in the rumen by feeding HMC discussed earlier in this paper. In addition, the pattern of diurnal fluctuation of the ruminal $\mathrm{pH}$ was similar among treatments, with the highest $\mathrm{pH}$ values observed just before morning feeding and the lowest $\mathrm{pH}$ values around $8 \mathrm{~h}$ after the feeding (Figure 1), which is very similar to the patterns from cows fed 20 or $40 \%$ HMC reported by Vagnoni and Broderick (1997). The ruminal $\mathrm{pH}$ averaged on an hourly basis was maintained above 6.0 in the current study, although there were some daily episodes of $\mathrm{pH}$ $<5.8$. Therefore, some effects of statistical tendencies due to feeding HMC and interaction effects would have biologically minor consequences on microbial physiology. Vagnoni and Broderick (1997) observed that mean ruminal $\mathrm{pH}$ was 6.12 and 6.05 when cows were fed $24 \% \mathrm{HMC}+75 \% \mathrm{AH}$ and $44 \% \mathrm{HMC}+50 \% \mathrm{AH}$, respectively. Although fermentation acids or proteolysis degrade prolamin-zein proteins during the ensiling process of HMC and lead to greater and more rapid ruminal starch fermentation in HMC (Hoffman et al., 2011), its effects on ruminal $\mathrm{pH}$ would not be detrimental when cows are fed HMC in an appropriate forage proportion in their diets.

Total VFA concentration, molar proportions of acetate and propionate, and acetate-to-propionate ratio were not affected by quality of $\mathrm{AH}$ and processing of corn grain (Table 5). The products of ruminal fermentation are related to the composition of the diet (Eun et al., 2004). In general, increasing ruminal fermentability of grain typically yields increased VFA concentration with a greater propionate proportion. However, decreased DMI due to feeding HMC in our study may have moderated the potential effects of feeding HMC on ruminal VFA profiles.

Ruminal $\mathrm{NH}_{3}-\mathrm{N}$ concentration tended to be greater $(P=0.09)$ for HAH compared with FAH, whereas feeding the HMC diet decreased the $\mathrm{NH}_{3}-\mathrm{N}$ concentration under the $\mathrm{HAH}$ diet, resulting in an $\mathrm{AH} \times \mathrm{CG}$ interaction. This result was likely due to greater fermentability of CP from HAH compared with FAH (Holt et al., 2013). Yield of MCP increased by feeding HAH diets compared with FAH diets, whereas feeding the HMC diet increased the MCP yield under the HAH diet, leading to an interaction between $\mathrm{AH}$ and $\mathrm{CG}$. The lower ruminal $\mathrm{NH}_{3}-\mathrm{N}$ concentration observed for HMC under the $\mathrm{HAH}$ diet can be attributed to increased utilization of ruminally degraded $\mathrm{N}$ for MCP synthesis due to feeding HMC. Rumen bacteria can utilize more $\mathrm{NH}_{3}-\mathrm{N}$ for MCP synthesis in the presence of readily available energy (NRC, 2001). As the ensiling process of HMC increases fermentability of grain starch, the utilization of $\mathrm{NH}_{3}-\mathrm{N}$ for $\mathrm{MCP}$ synthesis could have been greater in the HMC diet compared with the SFC diet, resulting in less $\mathrm{NH}_{3}-\mathrm{N}$ concentration in the HMC diet than in the SFC diet. Others reported a similar reduction in $\mathrm{ru}-$ minal $\mathrm{NH}_{3}-\mathrm{N}$ concentration when feeding HMC (Agca and Broderick, 1995; Vagnoni and Broderick, 1997), implying that the inclusion of HMC in dairy diets can stimulate the uptake of ruminal $\mathrm{NH}_{3}-\mathrm{N}$ and increase $\mathrm{N}$ utilization for milk production. These results suggest that enhancing the availability of ruminal fermentable energy can be an effective strategy to increase microbial capture of RDP from HAH. Supplementation of alfalfa silage with HMC increased milk protein yield by $260 \mathrm{~g} / \mathrm{d}$ (Cadorniga and Satter, 1993), presumably through enhanced ruminal MCP synthesis. The reduction of $\mathrm{NH}_{3}-\mathrm{N}$ concentration with feeding $\mathrm{HMC}$ under the HAH diet was likely due to greater fiber digestion in the rumen, and cellulolytic bacteria such as Ruminococcus albus, Ruminococcus flavefaciens, and Fibrobacter 


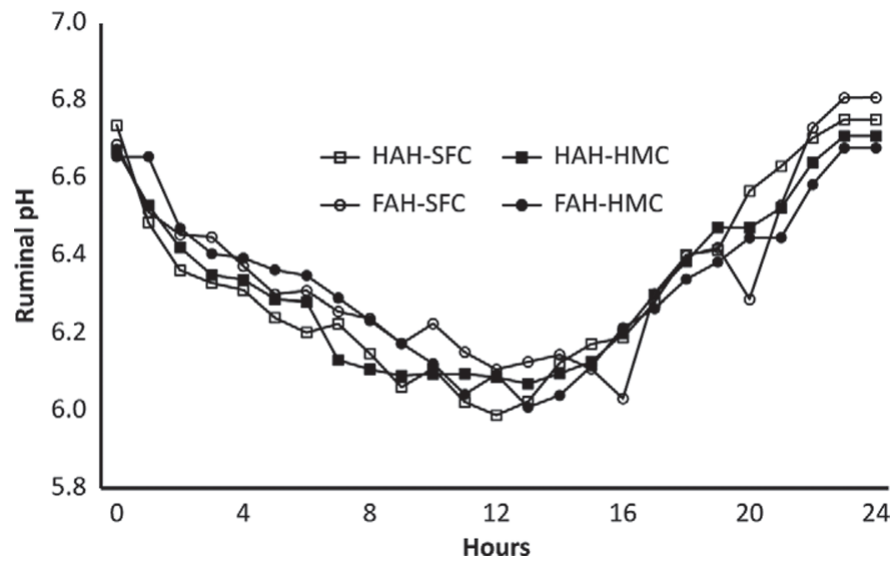

Figure 1. Effects of quality of alfalfa hay [fair-quality (FAH) vs. high-quality alfalfa hay (HAH)] and type of corn grain [(steam-flaked (SFC) vs. high-moisture corn (HMC)] on diurnal variation of ruminal $\mathrm{pH}$. The $\mathrm{pH}$ values were recorded every $30 \mathrm{~s}$ over a 48 -h period. Least squares means for culture $\mathrm{pH}$ were $6.33,6.31,6.30$, and 6.31 for FAHSFC, FAH-HMC, HAH-SFC, and HAH-HMC, respectively.

succinogenes require $\mathrm{NH}_{3}-\mathrm{N}$ as an $\mathrm{N}$ source for growth (Russell et al., 1992).

Energy spilling can occur when ruminal $\mathrm{pH}$ is low (Strobel and Russell, 1986), and under these conditions, MCP yield would decrease due to less energy available for microbial growth. However, this did not appear in the current study for the MCP yield observed for HMC compared with SFC treatment, because feeding HMC did not negatively influence ruminal $\mathrm{pH}$ profiles.

\section{CONCLUSIONS}

Our current study investigated if forage type interacted with grain processing, and whether the addition of highly digestible carbohydrate to an AH-based diet increased the energy available in ruminal fermentation and to the cow. Our hypothesis was confirmed in ruminal $\mathrm{NH}_{3}-\mathrm{N}$ concentration and $\mathrm{MCP}$ yield, but not in feed and $\mathrm{N}$ utilization efficiencies, as feeding HMC improved the efficiencies of feed and $\mathrm{N}$ for milk production, regardless of the quality of $\mathrm{AH}$. We found that feeding HMC depressed DM and nutrient intakes, regardless of quality of $\mathrm{AH}$, which partially contributed to the increased feed and $\mathrm{N}$ efficiencies. Contrary to previously reported results, we did not observe any negative results of feeding HMC on ruminal fermentation. Rather, we observed that feeding HMC increased fiber and CP digestibilities. These positive effects may have resulted from effective utilization of forage NDF in the diets, which could maintain favorable fermentative conditions of rumen microbes for $\mathrm{N}$ and energy metabolism. Thus, feeding HMC in AH-based diets can be a good approach to formulate an optimal dairy feeding program for improving feed efficiency and nutrient

Table 5. Ruminal fermentation characteristics of lactating dairy cows fed different qualities of alfalfa hay and types of corn grain

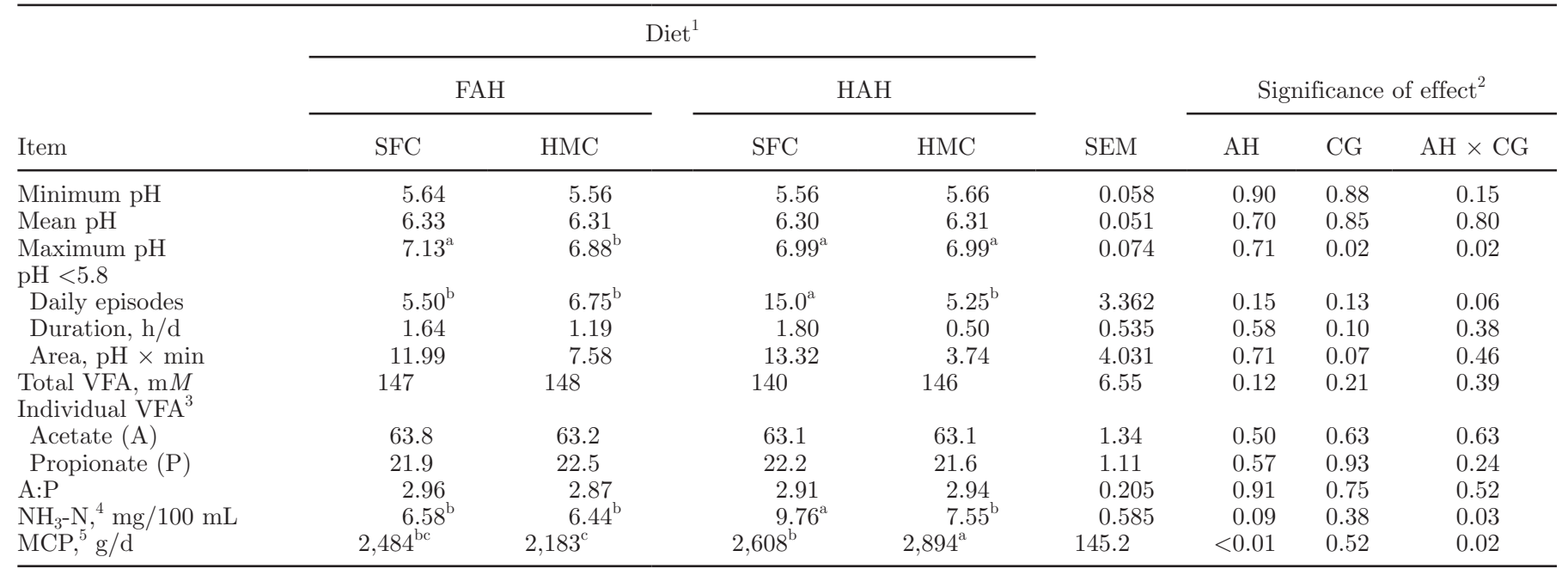

\footnotetext{
${ }^{\mathrm{a}-\mathrm{c}}$ Means within a row with different superscripts differ $(P<0.05)$.

${ }^{1} \mathrm{FAH}-\mathrm{SFC}=$ fair-quality alfalfa hay $(\mathrm{FAH})$ and steam-flaked corn (SFC) diet; FAH-HMC = FAH and high-moisture corn (HMC) diet; HAH$\mathrm{SFC}=$ high-quality alfalfa hay $(\mathrm{HAH})$ and $\mathrm{SFC}$ diet; HAH-HMC $=\mathrm{HAH}$ and $\mathrm{HMC}$ diet.

${ }^{2} \mathrm{AH}=$ quality of alfalfa hay in the diet (FAH vs. $\left.\mathrm{HAH}\right) ; \mathrm{CG}=$ type of corn grain in the diet (SFC vs. $\left.\mathrm{HMC}\right) ; \mathrm{AH} \times \mathrm{CG}=$ interaction between $\mathrm{AH}$ and $\mathrm{CG}$.

${ }^{3}$ Expressed as mol/100 mol.

${ }^{4}$ Ruminal $\mathrm{NH}_{3}-\mathrm{N}$.

${ }^{5}$ Microbial protein production $(\mathrm{g} / \mathrm{d})=\left(\left\{\right.\right.$ purine derivatives production $\left.\left.\left.-\left(0.385 \times \mathrm{BW}^{0.075}\right)\right] / 0.85\right\} \times 70 \times 6.25\right) /(0.13 \times 0.83 \times 1,000)(\mathrm{Janicek}$ et al., 2008).
} 
utilization, but its effect on depressed DMI should be considered. It is possible that if this study were repeated with early-lactation cows under negative energy balance conditions and more limited DMI, then different results might be found, showing increased DMI and milk production when the greater quality, earlier maturity AH was fed. If this study is repeated, it would be good to use corn of one variety with similar protein concentration to compare between the 2 physical forms as SFC and HMC to confirm the main finding in this study that conservation method and not varietal differences was the reason that the HMC was utilized so much more efficiently and beneficially in this study.

\section{ACKNOWLEDGMENTS}

This study was supported by funds from Utah State University Agricultural Experiment Station (Logan). The authors thank the staff of the Caine Dairy Center (Wellsville, UT) at Utah State University for their conscientious care of the experimental cows.

\section{REFERENCES}

Abdoun, K., F. Stumpff, and H. Martens. 2006. Ammonia and urea transport across the rumen epithelium: A review. Anim. Health Res. Rev. 7:43-59.

Agca, C., and G. A. Broderick. 1995. Effect of grinding of high moisture corn on yield of lactating cows fed alfalfa silage. J. Dairy Sci. 78(Suppl. 1):220. (Abstr.)

Allen, M. S. 2000. Effects of diet on short-term regulation of feed intake by lactating dairy cattle. J. Dairy Sci. 83:1598-1624.

AOAC International. 2000. Official Methods of Analysis. Vol. 1 and 2. 17th ed. AOAC Int., Gaithersburg, MD.

Beauchemin, K. A., and W. Z. Yang. 2005. Effects of physically effective fiber on intake, chewing activity, and ruminal acidosis for dairy cows fed diets based on corn silage. J. Dairy Sci. 88:2117-2129.

Britt, J. S., R. C. Thomas, N. C. Speer, and M. B. Hall. 2003. Efficiency of converting nutrient dry matter to milk in Holstein herds. J. Dairy Sci. 86:3796-3801.

Cadorniga, C. P., and L. D. Satter. 1993. Protein versus energy supplementation of high alfalfa silage diets for early lactation cows. J. Dairy Sci. 76:1972-1977.

Calsamiglia, S., P. W. Cardozo, A. Ferret, and A. Bach. 2008. Changes in rumen microbial fermentation are due to a combined effect of type of diet and pH. J. Anim. Sci. 86:702-711.

Chen, X. B., and M. J. Gomes. 1992. Estimation of microbial protein supply to sheep and cattle based on urinary excretion of purine derivatives - An overview of the technical details. Int. Feed. Res. Unit, Occas. Publ. Rowett Res. Inst., Bucksburn, Aberdeen, UK.

Clark, J. H., R. A. Frobish, K. E. Harshbarger, and R. G. Derrig 1973. Feeding value of dry corn, ensiled high moisture corn, and propionic acid treated high moisture corn fed with hay or haylage for lactating dairy cows. J. Dairy Sci. 56:1531-1539.

DePeters, E. J., and J. P. Cant. 1992. Nutritional factors influencing the nitrogen composition of bovine milk: A review. J. Dairy Sci. 75:2043-2070.

DRMS (Dairy Records Management Systems). 2014. DHI Glossary Accessed Apr. 20, 2014. http://www.drms.org/PDF/materials/ glossary.pdf.

Ekinci, C., and G. A. Broderick. 1997. Effect of processing high moisture ear corn on ruminal fermentation and milk yield. J. Dairy Sci. 80:3298-3307.
Eun, J.-S., and K. A. Beauchemin. 2005. Effects of a proteolytic feed enzyme on intake, digestion, ruminal fermentation, and milk production. J. Dairy Sci. 88:2140-2153.

Eun, J.-S., and K. A. Beauchemin. 2007. Enhancing in vitro degradation of alfalfa hay and corn silage using feed enzymes. J. Dairy Sci. 90:2839-2851.

Eun, J.-S., V. Fellner, and M. L. Gumpertz. 2004. Methane production by mixed ruminal cultures incubated in dual-flow fermentors. J. Dairy Sci. 87:112-121.

Firkins, J. L. 2008. Considerations associated with corn processing in dairy rations. Proc. Southwest Nutr. Management Conf., Tempe, AZ. Univ. of Arizona, Tucson.

Firkins, J. L., M. L. Eastridge, N. R. St-Pierre, and S. M. Noftsger. 2001. Effects of grain variability and processing on starch utilization by lactating dairy cattle. J. Anim. Sci. 79(E. Suppl.):E218E238.

Harvatine, D. I., J. L. Firkins, and M. L. Eastridge. 2002. Whole linted cottonseed as a forage substitute fed with ground or steam-flaked corn: Digestibility and performance. J. Dairy Sci. 85:1976-1987.

Hoffman, P. C., N. M. Esser, R. D. Shaver, W. K. Coblentz, M. P. Scott, and A. L. Bodnar. 2011. Influence of ensiling time and inoculation on alteration of the starch-protein matrix in high-moisture corn. J. Dairy Sci. 94:2465-2474.

Holt, M. S., K. Neal, J.-S. Eun, A. J. Young, J. O. Hall, and K. E. Nestor Jr. 2013. Corn silage hybrids and quality of alfalfa hay affect dietary nitrogen utilization by early lactating dairy cows. J. Dairy Sci. 96:6564-6576.

Holt, M. S., C. M. Williams, C. M. Dschaak, J.-S. Eun, and A. J. Young. 2010. Effects of corn silage hybrids and dietary nonforage fiber sources on feed intake, digestibility, ruminal fermentation, and productive performance of lactating Holstein dairy cows. J. Dairy Sci. 93:5397-5407.

Janicek, B. N., P. J. Kononoff, A. M. Gehman, and P. H. Doane. 2008. The effect of feeding dried distillers grains plus solubles on milk production and excretion of urinary purine derivatives. J. Dairy Sci. 91:3544-3553.

Knowlton, K. F., B. P. Glenn, and R. A. Erdman. 1998. Performance, rumen fermentation, and site of starch digestion in early lactation cows fed corn grain harvested and processed differently. J. Dairy Sci. 81:1972-1984.

Knudsen, K. E. B. 1997. Carbohydrate and lignin contents of plant materials used in animal feeding. Anim. Feed Sci. Technol. $67: 319-338$

Krause, K. M., D. K. Combs, and K. A. Beauchemin. 2002. Effects of forage particle size and grain fermentability in midlactation cows. I. Milk production and diet digestibility. J. Dairy Sci. 85:19361946.

Littell, R. C., P. R. Henry, and C. B. Ammerman. 1998. Statistical analysis of repeated measures data using SAS procedures. J. Anim. Sci. 76:1216-1231.

Maekawa, M., K. A. Beauchemin, and D. A. Christensen. 2002. Chewing activity, saliva production, and ruminal $\mathrm{pH}$ of primiparous and multiparous lactating dairy cows. J. Dairy Sci. 85:1176-1182.

Mertens, D. R. 2002. Nutritional implications of fiber and carbohydrate characteristics of corn silage and alfalfa hay. Pages 94-107 in California Animal Nutrition Conf., Fresno, CA. California State Univ., Fresno.

Nocek, J. E. 1997. Bovine acidosis: Implications on laminitis. J. Dairy Sci. 80:1005-1028.

Nocek, J. E., and S. Tamminga. 1991. Site of digestion of starch in the gastrointestinal tract of dairy cows and its effect on milk yield and composition. J. Dairy Sci. 74:3598-3629.

NRC. 2001. Nutrient Requirements of Dairy Cattle. 7th rev. ed. Natl. Acad. Sci., Washington, DC.

Oba, M., and M. S. Allen. 1999. Effects of brown midrib 3 mutation in corn silage on dry matter intake and productivity of high yielding dairy cows. J. Dairy Sci. 82:135-142.

Oba, M., and M. S. Allen. 2003. Effects of corn grain conservation method on feeding behavior and productivity of lactating dairy cows at two dietary starch concentrations. J. Dairy Sci. 86:174183. 
Owens, F., and S. Soderlund. 2006. Ruminal and postruminal starch digestions by cattle. Pages 116-128 in Proc. of Cattle Grain Processing Symp., Stillwater, OK. Oklahoma State Univ., Stillwater.

Penner, G. B., K. A. Beauchemin, and T. Mutsvangwa. 2006. An evaluation of the accuracy and precision of a stand-alone submersible continuous ruminal $\mathrm{pH}$ measurement system. J. Dairy Sci. $89: 2132-2140$

Rhine, E. D., G. K. Sims, R. L. Mulvaney, and E. J. Pratt. 1998. Improving the Berthelot reaction for determining ammonium in soil extracts and water. Soil Sci. Soc. Am. J. 62:473-480.

Russell, J. B., J. D. O'Connor, D. G. Fox, P. J. Van Soest, and C. J. Sniffen. 1992. A net carbohydrate and protein system for evaluating cattle diets: I. Ruminal fermentation. J. Anim. Sci. 70:35513561.

San Emeterio, F., R. B. Reis, W. E. Campos, and L. D. Satter. 2000. Effect of coarse or fine grinding on utilization of dry or ensiled corn by lactating dairy cows. J. Dairy Sci. 83:2839-2848.

SAS Institute. 2013. SAS/STAT Use's Guide. Release 9.4. SAS Institute Inc., Cary, NC.

Shingfield, K. J., and N. W. Offer. 1998. Evaluation of the spot urine sampling technique to assess urinary purine derivate excretion in lactating dairy cows. J. Anim. Sci. 66:557-568.

Shingfield, K. J., and N. W. Offer. 1999. Simultaneous determination of purine metabolites, creatinine, and pseudouridine in ruminant urine by reversed-phase high-performance liquid chromatography. J. Chromatogr. B Biomed. Sci. Appl. 723:81-94.
Strobel, H. J., and J. B. Russell. 1986. Effect of $\mathrm{pH}$ and energy spilling on bacterial protein synthesis by carbohydrate-limited cultures of mixed rumen bacteria. J. Dairy Sci. 69:2941-2947.

Vagnoni, D. B., and G. A. Broderick. 1997. Effects of supplementation of energy or ruminally undegraded protein to lactating cows fed alfalfa hay or silage. J. Dairy Sci. 80:1703-1712.

Valadares Filho, S. C., G. A. Broderick, R. F. D. Valadares, and M. K. Clayton. 2000. Effect of replacing alfalfa silage with high moisture corn on nutrient utilization and milk production. J. Dairy Sci. 83:106-114.

Van Keulen, J., and B. A. Young. 1977. Evaluation of acid-insoluble ash as a natural marker in ruminant digestibility studies. J. Anim. Sci. 44:282-287.

Van Soest, P. J., J. B. Robertson, and B. A. Lewis. 1991. Methods for dietary fiber, neutral detergent fiber, and nonstarch polysaccharides in relation to animal nutrition. J. Dairy Sci. 74:3583-3597.

Wilkerson, V. A., B. P. Glenn, and K. R. McLeod. 1997. Energy and nitrogen balance in lactating cows fed diets containing dry or high moisture corn in either rolled or ground form. J. Dairy Sci. 80:2487-2496.

Zogg, C. A., R. E. Brown, K. E. Harshbarger, and K. A. Kendall. 1961. Nutritive value of high-moisture corn when fed with various silages to lactating dairy cows. J. Dairy Sci. 44:483-490. 